\title{
Quality Characteristics of Functional Yoghurt with Fortification of Encapsulated Resveratrol Powder
}

\author{
Harshita Sonarthi, S. Sivakumar*, Rekha Chawla, N. Veena, S.K. Mishra, \\ Lovepreet Singh and P.K. Singh
}

College of Dairy Science and Technology, Guru Angad Dev Veterinary and Animal Sciences University, Ludhiana, Punjab, India

*Corresponding author

\section{A B S T R A C T}

\begin{tabular}{|l|l|l|}
\hline Keywords & $\begin{array}{l}\text { Yoghurt is a well-known fermented product popular in India and all over the world. The } \\
\text { objective of the present study was carried out to incorporate encapsulated resveratrol } \\
\text { powder into yoghurt and check the quality characteristics of it. The different proportions of } \\
\text { encapsulated resveratrol powder with whey protein isolate as wall material was added to } \\
\text { Encapsulated } \\
\text { resveratrol powder }\end{array}$ & $\begin{array}{l}\text { yoghurt. Based upon the sensory scores } 1 \% \text { level was finalized for further study. The } \\
\text { optimized yoghurt was compared with control for different proximate composition, } \\
\text { texture, colour parameters, antioxidant activity, resveratrol content and microbiological } \\
\text { parameters. Sensory results shows non-significant difference ( } \leq \leq 0.05) \text { between control and } \\
\text { optimized product (WPI 1\%) in all attributes. WPI based wall material used for } \\
\text { encapsulation of resveratrol powder could be successfully incorporated in yoghurt which } \\
\text { could serve as a potential delivery system of resveratrol for enhancing functionality of the } \\
\text { yoghurt. }\end{array}$ \\
\hline $\begin{array}{l}\text { Accepted: } \\
\text { Available Online: }\end{array}$ 10 August 2018
\end{tabular}

\section{Introduction}

"Yoghurt is a popular fermented dairy product produced by the cultures" consisting of Streptococcus salivarius subsp. thermophilus and Lactobacillus delbrueckii subsp. Bulgaricus. As per official website of National Dairy Development Board, India's milk production was increased from 55.6 million tonnes (1991-92) to 165.4 million tonnes (2016-17) (NDDB 2018). In India, 10\% of total milk produced is converted into fermented milk products like yoghurt, dahi, lassi etc. This sector is growing at more than $20 \%$ (Singh, 2011).
Yoghurt is famous due to the entry of a number of international and national organized dairy players in the market and gradually replaces the other dairy products due to its varieties and health benefits.

The period between 2011 and 2015, the yoghurt market in India grew at a compound annual growth rate (CAGR) of $28.9 \%$ and this market is projected to touch US\$1 Billion by the end of the year 2021.

Resveratrol (trans-resveratrol; trans-3,5,4trihydroxystilbene) is a polyphenol from the stilbenes family, found at relatively high 
levels in grape skins and also found in blueberries, raspberries, mulberries, peanuts and variety of other plant sources. Resveratrol having potential beneficial effects on human health, including cardio and neuro-protective, antioxidant, protects from infection and ischemia antiviral, prevents ageing, antiinflammatory, anti-carcinogenic, and antiobesity effects (Alves 2012). The major drawback for incorporating resveratrol into functional foods are related to degradation when exposed to oxygen and or light, low water solubility, low bioavailability (Hung et al., 2006).

In food industry, there is need for the edible delivery systems to encapsulate, protect and release resveratrol when developing functional food. Encapsulation is one of the most promising technologies having the feasibility to entrap bioactive compounds like resveratrol. The encapsulation further enhances the bioavailability, improve controlled release and enable precision targeting of the bioactive compounds in a greater extent (Mozafari et al., 2006). Keeping in view of this background, the present study was focused on to study the effect of encapsulated resveratrol powder on quality characteristics of yoghurt.

\section{Materials and Methods}

\section{Ingredients}

Fresh, clean, good quality mixed raw milk was obtained from Institute Experimental Dairy Plant. This milk was standardized by using skim milk. Skim milk was obtained by separating mixed milk in cream separator. Yoghurt starter cultures NCDC 144 ( $L$. bulgaricus and $S$. thermophilus) were procured from National Collection of Dairy Cultures, ICAR-NDRI, Karnal. Materials required for encapsulation like milk protein based wall materials like Whey protein isolate, Resveratrol, Soylecithin, Olive oil,
Maltodextrin, etc. were purchased from the reputed firms for preparation of encapsulated resveratrol powder. The packaging material polystyrene cups were procured from Institute Experimental Dairy Plant.

\section{Preparation of yoghurt}

Milk was standardized to $3 \%$ fat and $10 \%$ SNF with whole milk and skim milk by Pearson Square method. The standardized milk was heated to $85^{\circ} \mathrm{C}$ for $15 \mathrm{~min}$. The encapsulated resveratrol powder was incorporated at $70^{\circ} \mathrm{C}$. The milk was cooled to $42^{\circ} \mathrm{C}$, after that inoculation was done with $S$. thermophilus and L. bulgaricus@3\% at $42^{\circ} \mathrm{C}$. Then it was transferred to incubation room for incubation for 4-5 hours, once the desired acidity was reached it was transferred to cold storage at $5^{\circ} \mathrm{C}$.

\section{Sensory analysis}

The faculties from College of Dairy Science and Technology, GADVASU, Ludhiana participated in this study. Prior to sensory evaluation, sensory panel was briefed about the desirable characteristics of the product. Nine-point hedonic scale was employed to carry out the evaluation of samples for sensory attributes such as colour and appearance, texture, flavour and overall acceptability (Amerine et al., 1965). The nine-point hedonic scale includes various scales of grading i.e. liked extremely (9), liked very much (8), liked moderately (7), liked slightly (6), neither liked nor disliked (5), disliked slightly (4), disliked moderately (3), disliked very much (2), disliked extremely (1) (Lawless and Heymann 1998).

\section{Analytical procedures}

The brief description of different methods used to examine physicochemical properties of functional yoghurt is given below. 


\section{Physicochemical analysis}

Fat content, Protein content, ash content, titratable acidity of the product was done as per the method given by AOAC (2006). Moisture content was done by moisture analyzer. Syneresis of yoghurt samples were done by using the method as described by Hassan et al., (2015) with slight modifications.

\section{Texture profile analysis}

Various textural properties such as firmness, consistency, cohesiveness and index of viscosity were measured using Texture Analyser TA-XT Plus (M/s Stable Micro Systems, Surrey, UK) equipped with $5 \mathrm{~kg}$ load cell. A back extrusion test using $40 \mathrm{~mm}$ cylinder probe was used for texture profile analysis of the yoghurt samples. The product was subjected to compressive force by probe up to the distance of $30 \mathrm{~mm}$. For each evaluation, $(3 \times 3 \times 2.5) \mathrm{cm}^{3}$ size sample was used during texture analysis. Numerical values of textural values were measured using the exponent software (version 6.1.1.0). The conditions set in the Texture Analyser for measuring textural properties were as follows: Pre-Test Speed, $1 \mathrm{~mm} / \mathrm{s}$; Post-Test Speed, 1 $\mathrm{mm} / \mathrm{s}$; Test speed, $1 \mathrm{~mm} / \mathrm{s}$; Trigger force, 10.0 g; Time: $5.0 \mathrm{~s}$.

\section{Instrumental colour measurement}

Surface colour of yoghurt samples were measured using Colour Flex Colorimeter (Hunterlab, Reston, Virginia) supplied along with the universal software Easy Match QC (version 4.62) and the results were expressed in terms of CIE-LAB system. (Hunter 1975).

\section{Antioxidant activity of yoghurt}

Radical scavenging activity of the yoghurt incorporated with encapsulated resveratrol was determined by DPPH (2, 2 diphenyl-1picryl hydrazyl) method.

Resveratrol content in fortified yoghurt with encapsulated resveratrol powder

Reverse-Phase HPLC, Company-Waters, Detector: UV detector, Column $-\mathrm{C} 18$

Mobile phase-70(methanol):30(water), Flow rate $-0.8 \mathrm{ml} / \mathrm{minute}$. For the detection of resveratrol, the optimal wavelength of $306 \mathrm{~nm}$ was used. A Resveratrol concentration was determined by measuring the peak areas and comparing them with the peak areas of known standards. Sample preparation was carried out as per Kim et al., (2003) with slight modifications.

\section{Microbiological studies}

Lactic acid bacteria, yeast and mold count and coliform count were recorded as per procedure by Wehr and Frank (2004) using the media MRS and M17 for Lactic acid bacteria, Potato dextrose agar for yeast and mold and MacConkey for coliform.

\section{Results and Discussion}

\section{Effect of encapsulated resveratrol powder on sensory parameters of yoghurt}

Preliminary trials were conducted with broader ranges of different levels of milk protein based Whey protein isolate (WPI) encapsulated resveratrol powder in yoghurt. Three levels of fortificant encapsulated resveratrol powder $(0,1,2$ and $3 \%)$, were used during the development of product. Based upon sensory evaluation $1 \%$ levels of WPI based encapsulated resveratrol powder was selected considering its role as an enhancer of functionality. More than above levels lead to bitter taste in the final product. The values are shown in Figure 1. 
The values for colour and appearance were 8.11 and 7.85 respectively for control and optimized yoghurt i.e. WPI 1\%.wall materials based encapsulated resveratrol powder. In case of the body and texture, the scores obtained were 8.13 and 8 for Control and WPI 1\%. The score for flavour of yoghurts were like 8.07 and 7.82 for control and WPI 1\%. The lower acceptability in terms of flavor may be associated with the release of slightly higher amount of encapsulated resveratrol during pasteurization or fermentation process. When tried with selected level of incorporation of $1 \%$ WPI encapsulated powder, the entire sensory attribute like colour and appearance, body and texture, flavour and overall acceptability score shows no significant difference $(\mathrm{p} \leq 0.05)$ with control values.

Fermentation behavior during preparation of yoghurt with encapsulated resveratrol powder

\section{Titratable acidity}

The acidity during the fermentation period was checked after every one hour. The values were expressed in Figure 2. The initial acidity of the milk before inoculation was $0.13 \%$ LA. The acidity in both the samples after addition of culture increased immediately and ranged between 0.16 and 0.17 . The use of high amount of inoculum ( $3 \%$ of milk taken), higher total solids and protein content resulted in immediate increase in the acidity of the samples. The microbes got more protein due to incorporation of fortificant leads to increase in Titratable acidity. At the end of $5 \mathrm{~h}$ of incubation, the control yoghurt has shown the acidity of $0.828 \%$ which was ideal acidity for the yoghurt to be shifted to cold store (about $5^{0} \mathrm{C}$ ). While WPI $1 \%$ has shown $0.82 \%$ after 4: $30 \mathrm{hrs}$ and set earlier than control. The results findings are correlated with Lucey (2004) stated that an understanding of the gelation process during fermentation is critical in manipulating the physical properties of yoghurt. The rheological properties of acid gels are affected by different starter concentration and incubation temperatures, which directly affect the rate of acidification.

\section{pH}

During incubation period of yoghurt $\mathrm{pH}$ was taken after every one hour. The values were expressed in Figure 3. The initial $\mathrm{pH}$ of the milk used for yoghurt preparation was 6.64. At 0 hrs control yoghurt had $6.52 \mathrm{pH}$. But the yoghurt incorporated with encapsulated powder show lower $\mathrm{pH}$ at 0 hrs, WPI $1 \%$ (6.504). The control sample set at 5:00 hrs with $\mathrm{pH} 4.21$ and WPI 1\% set at 4:30 hrs with $4.23 \mathrm{pH}$. The slow fermentation is not desirable for yoghurt because of typical increases in syneresis and a breakdown of symbiotic relationship between starter bacteria (Tamime et al., 1989).

\section{Proximate composition of control and optimized yoghurt}

The milk was standardized (3\% fat, $10 \%$ SNF) and yoghurt was prepared as per the standard procedure with slight modifications. The incorporation of encapsulated resveratrol powder contains different components like oil, resveratrol and addition of protein based wall material (WPI) with addition of maltodextrin significantly $(\mathrm{p} \leq 0.05)$ affected the proximate composition of the samples. The compositions varied as follows, fat (3.00 to 3.56) protein (3.95 to 4.2 ) carbohydrates, (5.25 to 5.62) ash ( 0.80 to 1.05$)$. In addition to the lactose from milk, carbohydrates from encapsulated components (Maltodextrin) have contributed for the total carbohydrates in the experimental samples. Control yoghurt contains $0.80 \%$ minerals and experimental samples showed slightly higher minerals content, which could have been contributed by added encapsulated resveratrol components and proteins. 
Fig.1 Effect of encapsulated resveratrol powder on sensory parameters of yoghurt

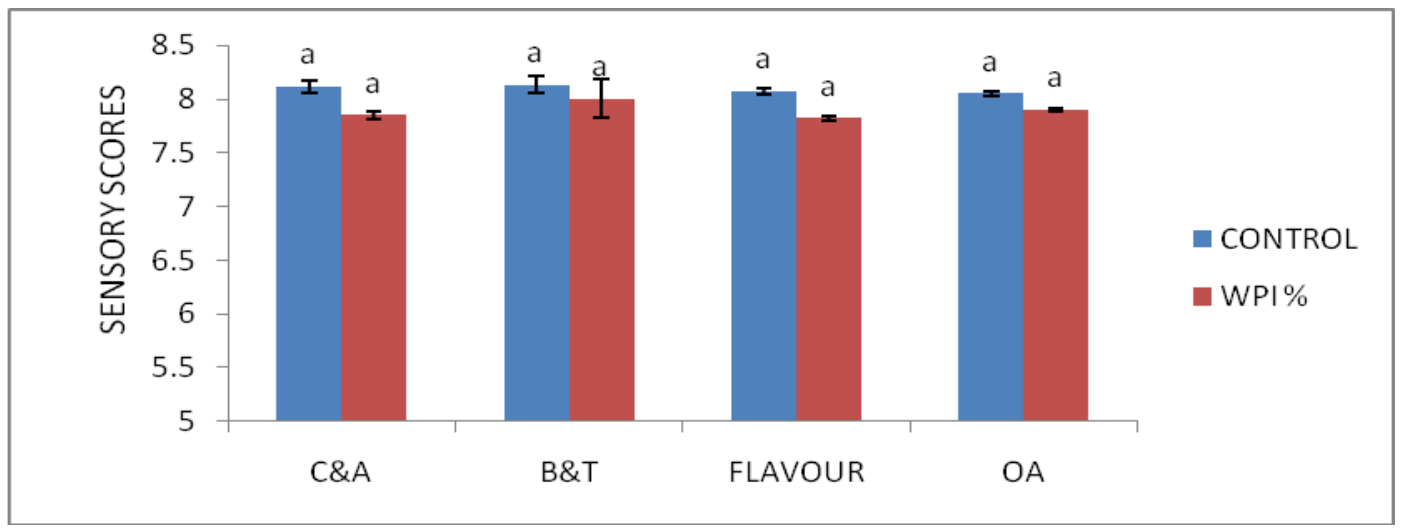

Average value $n=6$

Mean with different superscript differs significantly $(\mathrm{p} \leq 0.05)$ and all the values are expressed as $(\operatorname{mean} \pm \mathrm{SE})$.

Fig.2 Fermentation behavior (Changes in Titratable Acidity) during preparation of yoghurt with encapsulated resveratrol powder

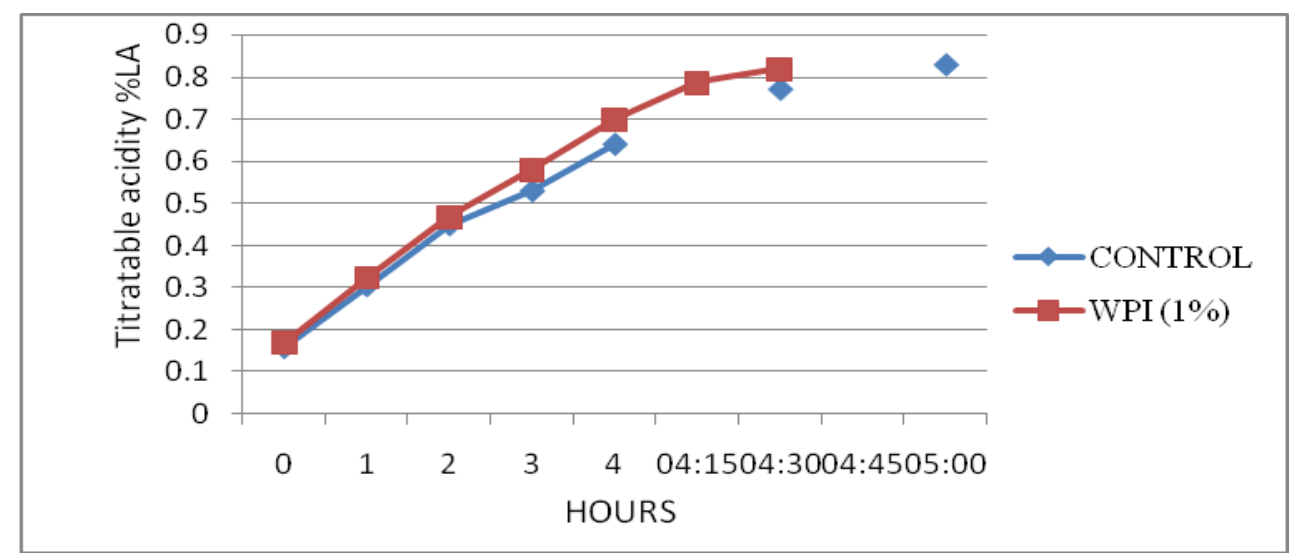

Average value $n=6$

Fig.3 Fermentation behavior (Changes in $\mathrm{pH}$ ) during preparation of yoghurt with encapsulated resveratrol powder

Average value $n=6$

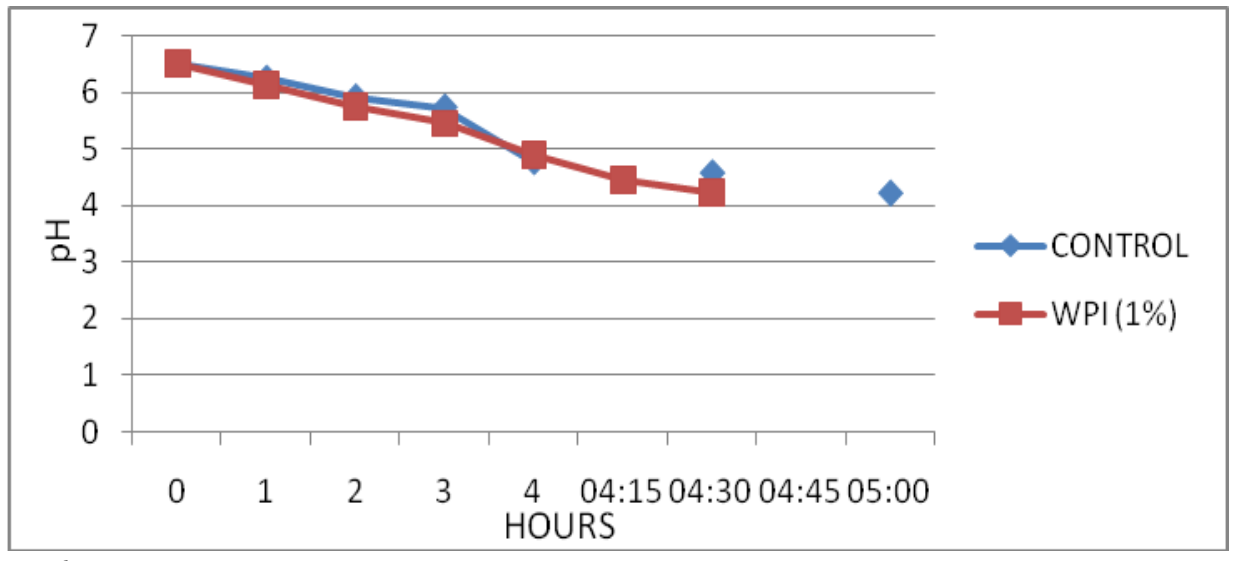


Table.1 Proximate composition of control and optimized yoghurt

\begin{tabular}{|l|}
\hline Parameter \\
\hline Fat \\
\hline Protein \\
\hline Carbohydrates \\
\hline Minerals \\
\hline Total solids \\
\hline Calorific value \\
\hline Acidity $(\%$ LA) \\
\hline pH \\
\hline Syneresis $(\mathbf{m l} / \mathbf{1 0 0 g})$ \\
\hline Antioxidant Activity \\
\hline Resveratrol content $(\mathbf{m g} / \mathbf{1 0 0 g})$ \\
\hline
\end{tabular}

\begin{tabular}{|c|c|}
\hline Control & WPI 1\% \\
\hline $3.00 \pm 0.05^{\mathrm{a}}$ & $3.56 \pm 0.01^{\mathrm{b}}$ \\
\hline $3.95 \pm 0.00^{\mathrm{a}}$ & $4.2 \pm 0.00^{\mathrm{b}}$ \\
\hline $5.25 \pm 0.01^{\mathrm{a}}$ & $5.62 \pm 0.01^{\mathrm{b}}$ \\
\hline $0.80 \pm 0.01^{\mathrm{a}}$ & $1.05 \pm 0.01^{\mathrm{b}}$ \\
\hline $13.00 \pm 0.03^{\mathrm{a}}$ & $14.41 \pm 0.00^{\mathrm{b}}$ \\
\hline $63.8 \pm 0.01^{\mathrm{a}}$ & $71.32 \pm 0.01^{\mathrm{b}}$ \\
\hline $0.85 \pm 0.00^{\mathrm{a}}$ & $0.86 \pm 0.00^{\mathrm{b}}$ \\
\hline $4.32 \pm 0.00^{\mathrm{b}}$ & $4.3 \pm 0.00^{\mathrm{a}}$ \\
\hline $2.61 \pm 0.01^{\mathrm{b}}$ & $2.31 \pm 0.01^{\mathrm{a}}$ \\
\hline $53.34 \pm 0.01^{\mathrm{a}}$ & $55.67 \pm 0.01^{\mathrm{b}}$ \\
\hline NIL & $34.102 \pm 0.00^{\mathrm{a}}$ \\
\hline
\end{tabular}

Average value $n=6$

Mean with different superscript differs significantly $(\mathrm{p} \leq 0.05)$ and all the values are expressed as $($ mean $\pm \mathrm{SE})$.

Table. 2 Texture, colour profile and microbiological parameters of control and optimized Yoghurt

\begin{tabular}{|l|c|c|}
\hline Parameter & Control & WPI 1\% \\
\hline Texture Profile parameters of Yoghurt & & \\
\hline Firmness(g) & $190.19 \pm 0.02^{\mathrm{a}}$ & $234.27 \pm 0.01^{\mathrm{b}}$ \\
\hline Consistency (g.sec) & $3974.49 \pm 0.01^{\mathrm{a}}$ & $4865 \pm 0.01^{\mathrm{b}}$ \\
\hline Cohesiveness(g) & $-55.04 \pm 0.01^{\mathrm{a}}$ & $-81.06 \pm 0.2^{\mathrm{b}}$ \\
\hline Index of Viscosity (g.sec) & $-112.53 \pm 0.01^{\mathrm{a}}$ & $-121.17 \pm 0.01^{\mathrm{b}}$ \\
\hline Colour Profile parameters of Yoghurt & & \\
\hline L & $90.16 \pm 0.03^{\mathrm{b}}$ & $87.76 \pm 0.02^{\mathrm{a}}$ \\
\hline A & $-1.73 \pm 0.02^{\mathrm{b}}$ & $-1.17 \pm 0.02^{\mathrm{a}}$ \\
\hline B & $9.88 \pm 0.01^{\mathrm{a}}$ & $11.46 \pm 0.03^{\mathrm{b}}$ \\
\hline Microbiological parameters of Yoghurt & & \\
\hline L. bulgaricus $(\log$ cfu/g) & $6.6 \pm 0.00^{\mathrm{a}}$ & $6.84 \pm 0.00^{\mathrm{b}}$ \\
\hline S. thermophilus $(\mathbf{l o g}$ cfu/g) & $6.88 \pm 0.00^{\mathrm{a}}$ & $6.94 \pm 0.00^{\mathrm{b}}$ \\
\hline Coliforms(cfu/g) & NIL & NIL \\
\hline Yeast and Mold(cfu/g) & NIL & NIL \\
\hline A & & \\
\hline
\end{tabular}

Average value $n=6$

Mean with different superscript differs significantly $(\mathrm{p} \leq 0.05)$ and all the values are expressed as $($ mean $\pm \mathrm{SE})$.

The results were correlated with the findings of Sivakumar et al., (2016). The proximate composition values are expressed in Table 1. The fresh control yoghurt showed the acidity value of $0.85 \% \mathrm{LA}$, while the corresponding value for experimental sample varied between $0.86 \%$ LA. Similarly the fresh control yoghurt showed the $\mathrm{pH}$ value of 4.32 , while the corresponding value for experimental sample was 4.3.The fresh control yoghurt has showed the syneresis of $2.61 \mathrm{ml}$ per $100 \mathrm{~g}$ of the sample, while the corresponding value for WPI $1 \%$ was $2.31 \mathrm{ml}$ per 100 gram of the sample. 
The antioxidant activity of control and optimized yoghurt values were varied in the range from 53.34 to $55.67 \%$.The antioxidant activity of optimized yoghurt values were high due to incorporation of different milk protein based wall materials and resveratrol component. Our results were correlated with the findings of Korhonen and Pihlanto (2006) stated that milk proteins, the most important source of bioactive peptides and an increasing number of bioactive peptides have been identified in milk protein hydrolysates and fermented dairy products. The resveratrol content of control was nil while WPI $1 \%$ show $34.102 \mathrm{mg} / 100 \mathrm{~g}$ of product. This was due to incorporation of encapsulated resveratrol component.

Texture, colour profile and microbiological parameters of control and optimized Yoghurt

Texture, colour profile and microbiological parameters of control and optimized Yoghurt values are expressed in Table 2. The firmness of control and optimized yoghurt values were varied in the range from 190.19 to $234.27(\mathrm{~g})$. Results indicated that firmness was the lowest in control and highest in the samples fortified with WPI based encapsulated resveratrol powder. The texture values firmness, consistency, cohesiveness and index of viscosity differed significantly $(p \leq 0.05)$ between control and optimized yoghurt. The texture values were interlinked between control and optimized yoghurt. The incorporation of encapsulated resveratrol powder decreased $(\mathrm{P} \leq 0.05)$ the value of $\mathrm{L}^{*}$ of the milk, therefore, it presented a darkening effect, probably due to the absorption of water by the fortificant, as $\mathrm{L}^{*}$ value of foods is associated to the amount of free water in the surface of a product more than the complete product. When fortificant was incorporated in yogurts, a*values towards less greenness and $\mathrm{b}^{*}$ values more yellowness and a decrease in
$L^{*}$ values less whiteness were observed Overall, colour profile parameters L, a, b differed significantly $(\mathrm{P} \leq 0.05)$ between the control and optimized yoghurt.

The control and optimized yoghurt the $L$. bulgaricus count varied in the range of 6.6 to $6.84(\log \mathrm{cfu} / \mathrm{g})$ and $S$. thermophilus varied in the range of 6.88 to $6.94(\log \mathrm{cfu} / \mathrm{g})$. The optimized yoghurts were having more viable beneficial bacteria due to protein components present in the fortified substances provide the source of nutrient. The coliform and yeast and mould counts were nil indicates may be the control and optimized products were prepared in good hygiene practices. All the values were within the prescribed limits of FSSAI (2011). The sensory scores of optimized yoghurt (1\% WPI protein based encapsulated powder) shows no significant difference $(p \leq 0.05)$ with control values. The fresh control yoghurt showed the acidity value of $0.85 \%$ LA, while the corresponding value for experimental sample varied between $0.86 \%$ LA. Texture and Colour profile parameters (L, a, b) differed significantly $(\mathrm{P} \leq 0.05)$ between the control and optimized yoghurt. The antioxidant activity of control and optimized yoghurt values were varied in the range from 53.34 to $55.67 \%$. The resveratrol content of optimized yoghurt was $34.102 \mathrm{mg} / 100 \mathrm{~g}$ of product. The microbiological standards are within the prescribed FSSAI Limits.

\section{References}

Alves, N.E.G., Valdes, S.T., Sileveria, C.M.M., and Duarte, H.S.D. 2012. Studies on mechanistic role of natural bioactive compounds in the management of obesity a.n overview. Open Nutraceuticals Journal, 5(1): 193.

Amerine, M.A., Roessler, E.B., Ough, C.S. and Enol Vitic, A.J. 1965. Acids and the Acid Taste. I. the Effect of $\mathrm{pH}$ and 
Titratable Acidity. American Journal of Enology and viticulture, 16(1): 29-37.

AOAC. 2006. Official methods of analysis, $18^{\text {th }}$ Edition. Association of Official Analytical Chemists, Washington, DC.

FSSR. 2011 Food Safety and Standard Regulations. Food Safety and Standard Authority of India, Ministry of Health and Family Welfare, Govt. of India, New Delhi

Hassan, L.K., Haggag, H.F., Elkalyoubi, M.H., Abd EL-Aziz, M., El-Sayed, M.M., and Sayed, A.F. 2015. Physicochemical properties of yoghurt containing cress seed mucilage or guar gum. Annals of Agricultural Sciences, 60(1): 21-8.

Hung, C.F., Chen, J.K., Liao, M.H., Lo, H.M., and Fang, J.Y. 2006. Development and evaluation of emulsion-liposomes blends for resveratrol delivery. Journal of Nanoscience and Nanotechnology, 6: 2950-58.

Hunter, R.S. 1975. Scales for measurements of color differences. In Meu.srremett/,t/' Appearance. WileyInterscience NY p 133.

Kim, D.J., Kim, S.K., Kim, M.H., Lee, H.B., and Lee, J.S. 2003. Analysis of transresveratrol contents of grape and grape products consumed in Korea. Korean Journal of Food Science and Technology, 35: 764-768.

Korhonen, H., and Pihlanto, A. 2006. Bioactive peptides: Production and functionality. International Dairy Journal, 16: 945-960.

Lawless, H.T., and Heymann, H. 1998. Sensory evaluation of food principles and practices. New York: Chapman \& Hall.

Lucey, J.A. 2004. Cultured dairy products: An overview of their gelation and texture properties. International Journal of Dairy Technology, 57: 77-84.

Mozafari, M.R., Flanagan, J., Matia-Merino, L., Awati, A., Omri, A., Suntres, Z.E., and Singh, H. 2006. Recent trends in the lipid- based nanoencapsulation of antioxidants and their role in foods. Journal of the Science of Food and Agriculture, 86(13): 2038- 45.

NDDB 2018. Milk production in India.http://www.nddb.org/English/St atistics /Pages/Milk-Production.aspx (Accessed on 20.5.2018).

Singh, R., 2011. Probiotics: The Indian Scenario. Proceedings of the International Conference on functional dairy foods held at NDRI Karnal during 16-19 Nov. 2011.

Sivakumar, S., Balasubramanyam, B.V., Rao, K.J., Dhas, P.H.A., and Surendra Nath, B. 2016. Effect of Flaxseed oil and Flour on Sensory, Physicochemical and Fatty acid profile of the Fruit Yoghurt. Journal of Food Science and Technology, 54(2): 368-378.

Tamime, A.Y., Kalab, M., and Davies, G. 1989. Rheology and Microstructure of strained yoghurt (labneh) made from cow's milk by three different methods. Food Microstructure, 8: 125 - 135.

Wehr, H.M., and Frank, J.F. 2004. Standard Methods for the Examination of Dairy Products 17th ed. Am. Public Health Assoc., New York USA.

\section{How to cite this article:}

Harshita Sonarthi, S. Sivakumar, Rekha Chawla, N. Veena, S.K. Mishra, Lovepreet Singh and Singh, P.K. 2018. Quality Characteristics of Functional Yoghurt with Fortification of Encapsulated Resveratrol Powder. Int.J.Curr.Microbiol.App.Sci. 7(08): 3102-3109. doi: https://doi.org/10.20546/ijcmas.2018.708.331 